\section{Evaluation of Griffith Buck Roses for Resistance to Black Spot}

\author{
Daren S. Mueller ${ }^{1}$, Mark L. Gleason ${ }^{1,3}$, Nicholas P. Howell ${ }^{2}$, \\ and Edward M. Moran ${ }^{2}$
}

AdDitional INDEX WORDs. Marssonina rosae, Diplocarpon rosae

Summary. Recently, roses (Rosa spp.) that require relatively little maintenance have gained in popularity in the United States. One group of these roses is the Griffith Buck roses, which were selected to survive the extremely cold winters of the northcentral United States. Many of these roses were rated qualitatively as having disease resistance when they were released, but their resistance levels to black spot (Marssonina rosae) have not been quantified, compared with each other, or rated against other resistant or susceptible roses. In a field trial in Iowa in 2005 and 2006 , 24 Griffith Buck roses that were originally described as disease resistant were compared with susceptible and resistant control cultivars for susceptibility to black spot. No fungicides were applied in either year. Plants were rated five times each year for black spot incidence, and also to assess overall plant appearance. Griffith Buck roses 'Carefree Beauty', 'Aunt Honey', 'Honeysweet', 'Earthsong', and 'Pearlie Mae' had significantly less black spot than many of the other cultivars. In addition, these cultivars also remained attractive and could be used in low-maintenance landscapes in the north-central United States, even under moderate black spot pressure.

$\mathrm{B}$ lack spot of roses, caused by the fungus Marssonina rosae (teleomorph $=$ Diplocarpon rosae), is the most important and damaging disease of roses in landscapes worldwide. The pathogen causes round to irregular coal black spots with fringed margins, primarily on the upper leaf surfaces. Infected leaves can turn yellow and often fall off. $M$. rosae survives unfavorable periods on fallen leaves and diseased canes. Repeated defoliation weakens plants, leading to fewer blooms, reduced growth, and heightened sensitivity to environmental stresses (e.g., drought conditions).

Although cultural practices such as planting in sunny locations, avoiding overhead irrigation, and removing fallen, diseased leaves can suppress black spot to a limited extent, the most effective control measures are applying fungicide sprays and planting resistant cultivars. Intensive fungicide spray programs are unacceptable to many rose gardeners, however, and have drawn increased public concern due to perceived health and environmental hazards of chemical pesticides.

\footnotetext{
${ }^{1}$ Iowa State University, Department of Plant Pathology, Ames, IA 50011

${ }^{2}$ Iowa State University, Department of Horticulture, Ames, IA 50011

${ }^{3}$ Corresponding author. E-mail: mgleason@iastate.edu.
}

Most modern hybrid tea roses are highly susceptible to black spot. Attempts to transfer resistance from species to hybrid roses by crossing have often failed, however, due to chromosomal mismatch of the diploid species with the tetraploid hybrids (Walker et al., 1996). Despite decades of concerted effort, developing rose cultivars that combine meaningful levels of black spot resistance with desirable horticultural traits remains a major challenge (CarlsonNilsson and Davidson, 2006).

In the north-central United States, the challenge of breeding for black spot resistance is compounded by the need for tolerance to the extremely low winter temperatures typical of the region. Although many cultivar evaluations for black spot resistance have been conducted in the southern and eastern United States (e.g., Hagan et al., 2005), northern Europe (e.g., CarlsonNilsson and Davidson, 2006), and Japan (Chatani et al., 1996), only a few such trials have focused on cultivars adaptable to the north-central United States (Palmer and Salac,
1977; Watkins and Steinegger, 1986). Rose producers and gardeners in this region need clearer guidelines to select cultivars that not only resist black spot but also survive the climate.

While he was a professor at Iowa State University, Griffith Buck developed more than 80 new rose cultivars, primarily shrub types, which were released between 1962 and 1997. A primary aim of his breeding program was to develop cultivars that were sufficiently robust not only to survive Iowa winters (with minimum temperatures as low as $-35{ }^{\circ} \mathrm{C}$ ), but also to retain their foliage all season without fungicide sprays. Buck's breeding program was among the first in the world to focus on roses that were relatively easy to care for, even in challenging environments. Recently, rising public interest in low-maintenance roses has led to renewed interest in Griffith Buck roses, and many Griffith Buck roses are becoming more widely sold and planted.

Although Griffith Buck roses were not selected explicitly for black spot resistance, many of his releases possess some resistance or tolerance to the disease. However, no published studies have compared black spot resistance in relation to other resistant or susceptible cultivars, and Buck never compared levels of black spot resistance among his releases. The objective of our study was to assess resistance to black spot in 24 commercially available Griffith Buck roses that were rated as disease resistant when released, and to compare their resistance and landscape performance to highly black spotresistant and -susceptible control cultivars.

\section{Materials and methods}

Plot Setur and maintenance. A field plot was established on 19 May 2004 at Reiman Gardens on the campus of Iowa State University, Ames. The experimental design was a randomized complete block design with seven blocks. Within each block,

\begin{tabular}{llll}
\hline $\begin{array}{l}\text { Units } \\
\begin{array}{l}\text { To convert U.S. to SI, } \\
\text { multiply by }\end{array}\end{array}$ & U.S unit & SI unit & $\begin{array}{l}\text { To convert SI to U.S., } \\
\text { multiply by }\end{array}$ \\
\hline 48.8243 & $\mathrm{lb} / 1000 \mathrm{ft}^{2}$ & $\mathrm{~kg}^{\circ} \cdot \mathrm{ha}^{-1}$ & 0.0205 \\
$\left({ }^{\circ} \mathrm{F}-32\right) \div 1.8$ & ${ }^{\circ} \mathrm{F}$ & ${ }^{\circ} \mathrm{C}$ & $\left(1.8 \times{ }^{\circ} \mathrm{C}\right)+32$
\end{tabular}


each cultivar was represented by a single plant. We evaluated $24 \mathrm{com}$ mercially available Griffith Buck roses that were originally rated by Dr. Buck as disease resistant, along with two control (non-Buck) cultivars: Raven (highly susceptible) and Baby Love (highly resistant).

Plants were mulched with composted wood chips, fertilized with $10 \mathrm{~N}-4.4 \mathrm{P}-8.3 \mathrm{~K}$ fertilizer (l lb/ $1000 \mathrm{ft}^{2}$ nitrogen applied annually in early May and mid-July), irrigated by overhead sprinklers, weeded, deadheaded, and treated with insecticides as needed. Each winter, roses were protected against winter injury by straw mulching, as recommended by Iowa State University Extension (Jauron, 2006). In 2004, the plot was sprayed weekly with thiophanate-methyl $\left(3336^{\circledR}\right.$ WP; Cleary Chemical Corp., Dayton, NJ) alternated with chlorothalonil (Daconil Ultrex $^{\circledR}$; Syngenta Professional Products, Greensboro, NC) to facilitate plant establishment. No fungicides were used in 2005 or 2006.

Data COLLECTION AND ANALYSIS. Plants were assessed four times in 2005 (from 27 June to 30 Aug.) and seven times in 2006 (from 9 June to 13 Sept.). Each evaluation included two rating scales, one to assess black spot incidence and the other to assess landscape performance. For each black spot rating, two individuals estimated the percentage of leaves with black spot symptoms. For each date, ratings by the two individuals were averaged. The area under the disease progress curve (AUDPC) (Tooley and Grau, 1984) was calculated annually from incidence estimates on all rating dates. Defoliated leaves were taken into consideration when calculating disease incidence. Landscape performance was rated on a qualitative 1 to 10 scale based on relative plant size, plant health, and flowering and foliage color, with 1 representing the poorest performance and 10 representing the best performance. This scale is a modification of the Texas A\&M "resource efficiency" scale (Texas A\&M University, 2007), which is designed to evaluate the appearance of roses as a landscaper or gardener is likely to do. Plants rated as $\geq 5$ were considered to be of acceptable quality. Mean separations were assessed using Fisher's protected least significant difference at $P=0.05$
(SAS version 9.1; SAS Institute, Cary, NC).

\section{Results}

There were significant interactions of dependent variables with year (D.S. Mueller, unpublished data), therefore data were analyzed separately for each year. Overwinter survival was generally greatest on cultivars with the highest landscape performance and black spot resistance (Tables $1-3$ ). In some cultivars, only three or four (of the original total of seven) plants survived the 3 years. Mean performance ratings ranged from 2.9 to 6.0 in 2005 and 2.1 to 6.7 in 2006. Landscape performance ratings declined for both control cultivars from 2005 to 2006 (Table 1).

The susceptible control, 'Raven', had black spot on $>72 \%$ of its leaves by

Table 1. Landscape performance ratings for 24 Griffith Buck roses and two control cultivars at Reiman Gardens of Iowa State University, Ames, in 2005 and 2006.

\begin{tabular}{|c|c|c|c|}
\hline \multirow[b]{2}{*}{ Cultivar } & \multirow{2}{*}{$\begin{array}{c}\text { Plants } \\
\text { survived (no.) } \\
\end{array}$} & \multicolumn{2}{|c|}{$\begin{array}{l}\text { Landscape performance } \\
(1-10 \text { scale })^{\mathrm{y}}\end{array}$} \\
\hline & & 2005 & 2006 \\
\hline Habanera & 3 & $2.9 \mathrm{i}$ & $2.1 \mathrm{~h}$ \\
\hline Paloma Blanca & 4 & $3.0 \mathrm{i}$ & $2.5 \mathrm{f}-\mathrm{g}$ \\
\hline Queen Bee & 4 & $3.3 \mathrm{hi}$ & $3.0 \mathrm{e}-\mathrm{g}$ \\
\hline Mavourneen & 6 & $3.3 \mathrm{hi}$ & $2.3 \mathrm{gh}$ \\
\hline Princess Verona & 4 & $3.6 \mathrm{~g}-\mathrm{i}$ & $2.7 \mathrm{f}-\mathrm{h}$ \\
\hline Gentle Persuasion & 4 & $4.2 \mathrm{fg}$ & $2.6 \mathrm{f}-\mathrm{h}$ \\
\hline Sunbonnet & 5 & $4.1 \mathrm{fg}$ & $2.3 \mathrm{gh}$ \\
\hline Wild Ginger & 5 & $4.2 \mathrm{fg}$ & $2.4 \mathrm{gh}$ \\
\hline Prairie Sunrise & 6 & $4.6 \mathrm{~d}-\mathrm{f}$ & $2.4 \mathrm{f}-\mathrm{h}$ \\
\hline El Catala & 7 & $4.3 \mathrm{e}-\mathrm{g}$ & $2.9 \mathrm{f}-\mathrm{h}$ \\
\hline Les Sjulin & 5 & $4.1 \mathrm{fg}$ & $3.1 \mathrm{e}-\mathrm{g}$ \\
\hline Pipedreams & 6 & $4.8 \mathrm{c}-\mathrm{f}$ & $4.0 \mathrm{de}$ \\
\hline Winter Sunset & 7 & $5.2 \mathrm{~b}-\mathrm{d}$ & $4.6 \mathrm{~cd}$ \\
\hline Piccolo Pete & 7 & $5.3 \mathrm{a}-\mathrm{d}$ & $4.6 \mathrm{~cd}$ \\
\hline Hermina & 7 & $5.5 \mathrm{a}-\mathrm{c}$ & $4.7 \mathrm{~cd}$ \\
\hline Quietness & 7 & $5.6 \mathrm{a}-\mathrm{c}$ & $4.6 \mathrm{~cd}$ \\
\hline Pearlie Mae & 7 & $5.9 \mathrm{a}$ & $4.3 \mathrm{~d}$ \\
\hline Prairie Breeze & 7 & $5.6 \mathrm{a}-\mathrm{c}$ & $4.7 \mathrm{~cd}$ \\
\hline Honeysweet & 7 & $5.8 \mathrm{ab}$ & $4.6 \mathrm{~cd}$ \\
\hline Applejack & 7 & $5.5 \mathrm{a}-\mathrm{c}$ & $5.5 \mathrm{bc}$ \\
\hline Aunt Honey & 7 & $5.8 \mathrm{ab}$ & $5.3 \mathrm{bc}$ \\
\hline Earthsong & 7 & $5.7 \mathrm{a}-\mathrm{c}$ & $6.1 \mathrm{ab}$ \\
\hline Prairie Squire & 7 & $6.0 \mathrm{a}$ & $6.1 \mathrm{ab}$ \\
\hline Carefree Beauty & 7 & $5.9 \mathrm{ab}$ & $6.7 \mathrm{a}$ \\
\hline Raven (control) & 7 & $3.9 \mathrm{gh}$ & $2.7 \mathrm{f}-\mathrm{h}$ \\
\hline Baby Love (control) & 7 & $5.5 \mathrm{a}-\mathrm{c}$ & $4.7 \mathrm{~cd}$ \\
\hline $\operatorname{LSD}(0.05)^{x}$ & - & 0.7 & 0.9 \\
\hline
\end{tabular}

${ }^{2}$ Number of plants (of seven planted in 2004) that remained alive at the end of the study.

${ }^{y}$ Landscape performance rating scale is qualitative, and is based on size, plant health, flowering, and foliage color, as well as disease and insect damage, with $1=$ poorest performance and $10=$ best performance. Ratings shown are averaged from four observations in 2005 (from 27 June to 30 Aug.) and seven times in 2006 (from 9 June to 13 Sept.).

'Fisher's protected least significant difference at $P=0.05$. the end of the 2005 and 2006 growing seasons (Tables 2 and 3 ). In contrast, black spot symptoms were absent in 2005 on the resistant con$<6 \%$ of the leaves in 2006. In 2005, 3677 and 'Baby Love' had a value of 3 . Eight cultivars (Les Sjulin, Winter Sunset, Piccolo Pete, Pearlie Mae, Earthsong, Honeysweet, Aunt Honey, and Carefree Beauty) had AUDPC values that were not significantly different from that of 'Baby Love' in 2005. In 2006, 'Raven' had an AUDPC value of 5107 and 'Baby Love' had a value of 170 . Five culti(Prairie Squire, Piccolo Pete, Earthsong, Aunt Honey, and Carefree Beauty) had AUDPC values that of 'Baby Love'. trol, 'Baby Love', and occurred on 
Table 2. Incidence of black spot on Griffith Buck roses in field trials at Reiman Gardens of Iowa State University, Ames, in 2005 .

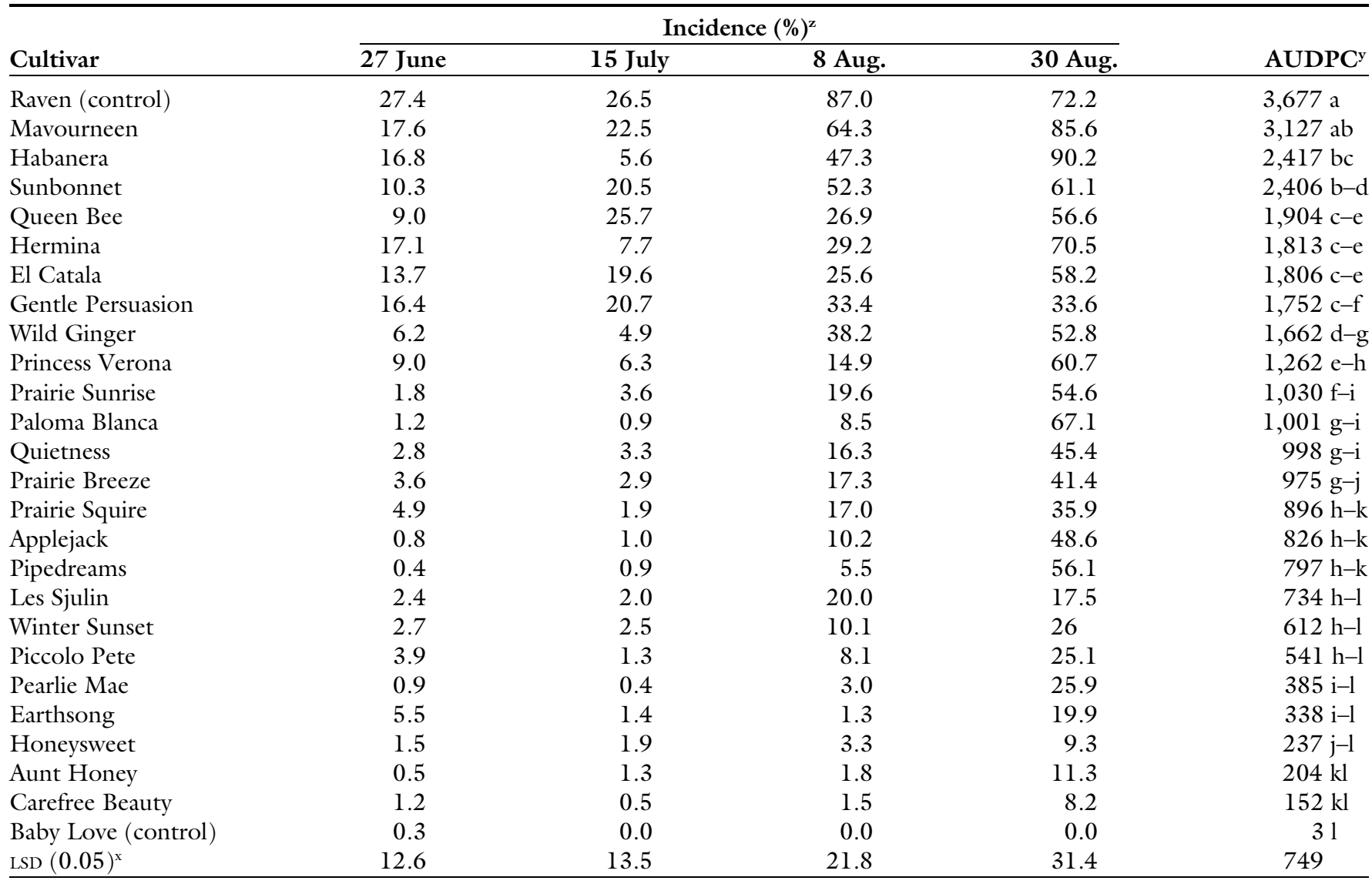

${ }^{2}$ Percentage of leaves with black spot symptoms.

yAUDPC = area under the disease progress curve calculated from four ratings from 27 June to 30 Aug. 2005.

xisher's protected least significant difference at $P=0.05$.

\section{Discussion}

Our findings are the first published assessment of black spot resistance and landscape performance among Griffith Buck roses. These ratings will be valuable to plant producers, landscapers, gardeners, and extension educators in the north-central United States, not only because they identify the top performers among the Griffith Buck roses, but also because they add to the small number of published comparisons of cultivar resistance to black spot that have been done in this region (Palmer and Salac, 1977; Watkins and Steinegger, 1986). Because relatively few commercial rose cultivars have meaningful levels of resistance to black spot (CarlsonNilsson and Davidson, 2006), and because the Griffith Buck roses represent the largest collection of cultivars bred to tolerate the harsh climatic conditions of the north-central United States, the best cultivars identified here should be promising choices for a range of landscapes, especially where low-maintenance, pesticidefree plantings are preferred. Cultivars Aunt Honey, Carefree Beauty, Honeysweet, Earthsong, Prairie Squire, and Pearlie Mae were among the most promising choices for their high landscape quality and strong tolerance to black spot. Because of apparent regional differences within the United States in virulence of predominant $M$. rosae races (Bolton and Svejda, 1979), as well as in environmental conditions and composition of the rose disease complex (Palmer et al., 1966), field trials for black spot resistance are likely to be most applicable within the region where they are conducted.

Disease severity increased from 2005 to 2006, as indicated by a general decrease in landscape performance ratings and increase in black spot incidence. Black spot developed earlier in the 2006 season than in 2005; this may have been due to greater overwintering of inoculum from the 2005 season because fungicides had been used to suppress the disease in 2004. Environmental conditions were similar in the 2005 and 2006 seasons: 2005 and 2006 were relatively dry in June and July.

In general, black spot severity ratings were inversely proportional to landscape performance; that is, cultivars with more severe disease development rated lower in landscape performance. An exception was 'Prairie Squire', which despite a disease incidence of $35 \%$ at the final rating in 2005, received one of the highest landscape performance ratings. This result indicates that 'Prairie Squire' remained attractive, even with substantial black spot-infected foliage, attesting to Dr. Buck's success is breeding cultivars with meaningful levels of tolerance to the disease.

There was very little disease or insect pressure other than black spot. A few cultivars (Paloma Blanca and 
Table 3. Incidence of black spot on Griffith Buck roses in field trials at Reiman Gardens of Iowa State University, Ames, in 2006

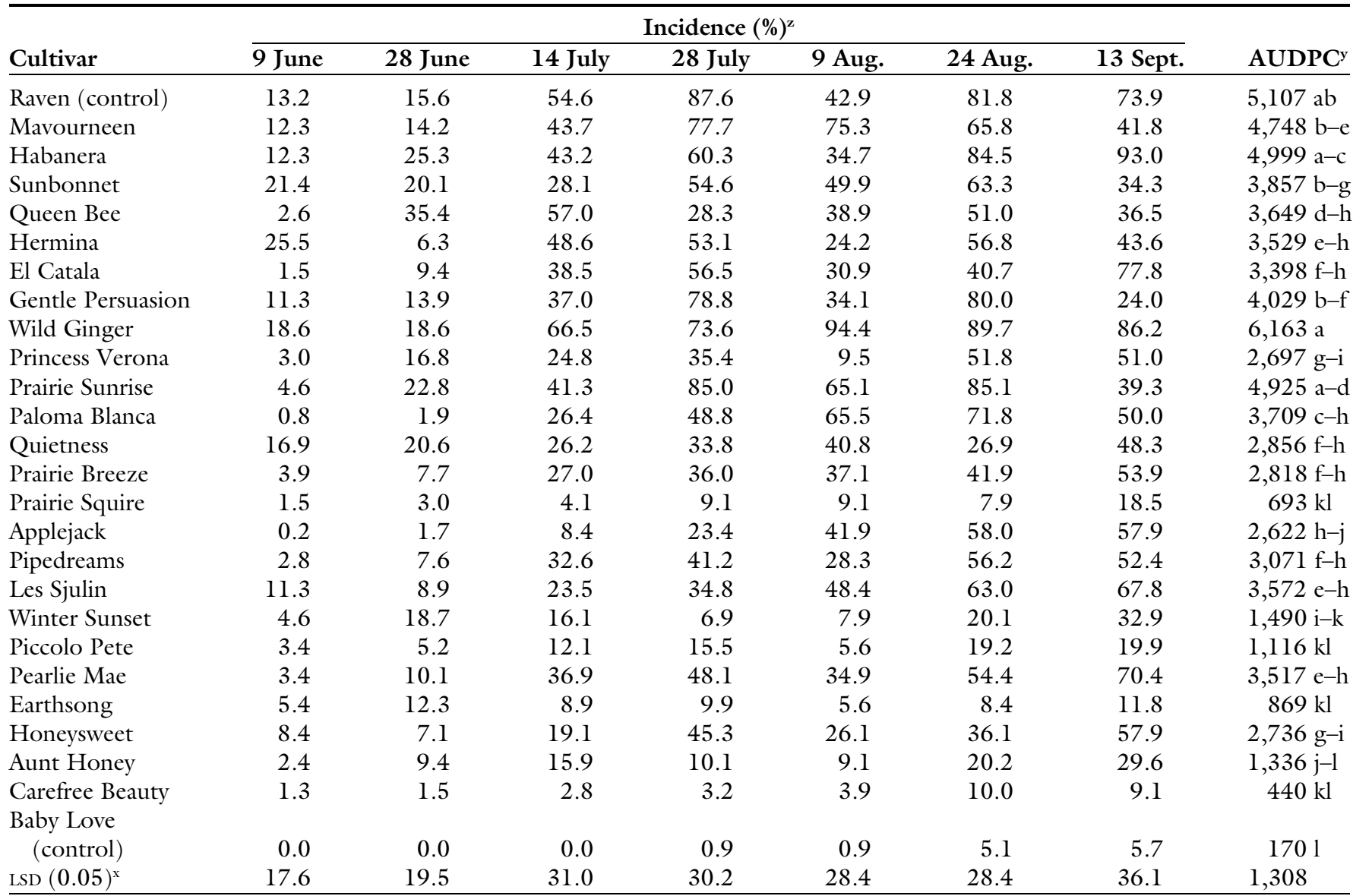

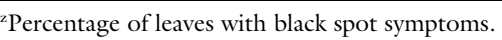

${ }^{y}$ AUDPC $=$ area under the disease progress curve calculated from four ratings from 9 June to 14 Sept. 2006.

${ }^{x}$ Fisher's protected least significant difference at $P=0.05$.

Princess Verona) had virus-like symptoms, possibly caused by rose rosette disease (Amrine and Hindal, 1988), and japanese beetles (Popillia japonica) were seen at low levels in 2006 on a few plants.

\section{Literature cited}

Amrine, J.W. and D.F. Hindal. 1988. Rose rosette: A fatal disease of multiflora rose. West Virginia Univ. Circ. 147.

Bolton, A.T. and F.J. Svejda. 1979. A new race of Diplocarpon rosae capable of causing severe blackspot on Rosa rugosa hybrids. Can. Plant Dis. Survey 59:38-43.

Carlson-Nilsson, B.U. and C.G. Davidson. 2006. Variation in resistance to Marssonina rosae among different $R o s a \mathrm{~L}$. cultivars and species including three dogrose species (Rosa sect. Caninae). Scientia Hort. 109:353-360.
Chatani, K., H. Toyoda, Y. Ogata, K. Koreeda, K. Yoshida, Y. Matsuda, K. Tsujina, and S. Ouchi. 1996. Evaluation of resistance of rose cultivars and wild rose to powdery mildew and black spot. Ann. Phytopathol. Soc. Jpn. 62:202-206.

Hagan, A.K., M.E. Rivas-Davila, J.R. Akridge, and J.W. Olive. 2005. Resistance of shrub and groundcover roses to black spot and Cercospora leaf spot, and impact of fungicide input on the severity of both diseases. J. Environ. Hort. 23:77-85.

Jauron, R. 2006. Caring for roses in Iowa. Iowa State Univ. Ext. Bul. RG 310.

Palmer, L.T. and S.S. Salac. 1977. Reaction of several types of roses to black spot fungus, Diplocarpon rosae. Indian Phytopathol. 30:366-368.

Palmer, J.G., P. Semeniuk, and R.N. Stewart. 1966. Roses and blackspot. I. Pathogenicity to excised leaflets of
Diplocarpon rosae from seven geographic locations. Phytopathology 56:12771282.

Texas A\&M University. 2007. Earth Kind: Environmental stewardship program. 14 Nov. 2007. <http://earthkind. tamu.edu/>

Tooley, P.W. and C.R. Grau. 1984. Field characterization of rate-reducing resistance to Phytophthora megasperma f. sp. glycinea in soybean. Phytopathology 74 : 1201-1208.

Walker, S., Z. Mandegaran, and A.V. Roberts. 1996. Screening roses for resistance to Diplocarpon rosae. Acta Hort. 424:209-214.

Watkins, J.E. and D.H. Steinegger. 1986. Reaction of rose cultivars to black spot and powdery mildew, 1980-1982. Biol. Cultural Tests 1:70. 